(C) 2013

Пономаренко С. В., аспірант *

Полтавська державна аграрна академія

\title{
ІСТОРІЯ, ЗАКОНОМІРНОСТІ ТА ПРОГНОЗУВАННЯ МАСОВОГО РОЗМНОЖЕННЯ ОСНОВНИХ ВИДІВ ШКІДНИКІВ КАПУСТИ В ЛІВОБЕРЕЖНОМУ ЛІСОСТЕПУ УКРАЇНИ
}

\section{Рецензент - кандидат сільськогосподарських наук М. М. Маренич}

\begin{tabular}{|} 
Проаналізовано сучасні погляди на можливість \\
використання екологічних чинників (сонячної \\
активності) для прогнозування масового розмно- \\
ження популяиій комах-шкідників на прикладі ос- \\
новних шкідників капусти в умовах Лівобережного \\
Лісостепу Украӥни. Враховуючи актуальність про- \\
гнозування масового розмноження основних лис- \\
тогризучих шкідників капусти з ряду лускокрилих \\
(совки капустяної (Матеstra brаssicaсеа L.), білана \\
капустяного (Ріегіs brassicaсеа L.), виконано рет- \\
роспективний аналіз історичних даних про масові \\
розмноження останніх у просторі й часі та роз- \\
роблено якісний прогноз їх появи на території \\
Полтавської області.
\end{tabular}

Ключові слова: капуста, икідники, динаміка чисельності популяцій, прогноз, екологічні чинники, реперні роки, капустяна совка, білан капустяний, прогноз.

Постановка проблеми. Масові розмноження шкідливих комах як історичні явища мають часові вимірювання: минуле, нинішне і майбутнє. Тому прогнозування їх масових розмножень це історія, що зорієнтована з минулого в майбутнє. Таке порівняння має певний сенс: відомо, що між прогнозованим і минулим має місце симетрія, віссю якої $є$ нинішнє, а тому прогнозування масового розмноження шкідливих комах - це відображення історії в часі [1].

Аналіз основних досліджень і публікацій, у яких започатковано розв'язання проблеми. Відомо, що історичні хроніки вже містять у собі інформацію про вплив у минулому на динаміку популяцій комах практично всіх середовищних чинників (космічних, геофізичних, біологічних, трофічних та ін.). Комахи, як одна $з$ найстародавніших груп тварин (з'явилися на Землі понад 400 млн років тому), мають генетичну пам'ять у минулому і передають інформацію від покоління до покоління за допомогою генетичного коду, згідно дарвінівської еволюційної тріади: спадко- вість, мінливість, природний добір, особливо під час масових розмножень, які повторюються циклічно, тобто через різні проміжки часу. Проте популяційні цикли комах аж ніяк не означають однаковості минулого і майбутнього. Відомо, що повторюваність у часі містить ознаки минулого, але вже на новій основі (при цьому закономірно змінюється генетична й екологічна організації популяцій), а тому всі без виключення фітосанітарні прогнози мають імовірний характер. Більше того, край велика мінливість біологічних популяцій у часі накладає певну заборону щодо прогнозування їх кількісних показників (щільності й чисельності). Зазвичай служби фітосанітарного моніторингу та прогнозування вже протягом близько століття будують річні прогнози на основі обстежень із використанням кількісних показників. Такі прогнози, як підтверджують дослідження сучасних провідних вчених-прогнозистів, ніколи не виправдовуються. Це підтвердила історія «несподіваних» масових розмножень шкідливих комах у різних регіонах світу. Тому нині можна із повною ймовірністю прогнозувати лише прогнозні сценарії (тобто, якісні прогнози), які відповідають на актуальні запитання виробництва: де і коли слід очікувати початку наступного масового розмноження того чи іншого шкідника [1].

Мета дослідження: враховуючи актуальність прогнозування масового розмноження основних листогризучих шкідників капусти 3 ряду лускокрилих (совки капустяної (Mamestra brassicacea L.), білана капустяного (Pieris brassicacea L.)), виконати ретроспективний аналіз історичних даних про масові розмноження останніх у просторі й часі.

Завдання дослідження: розробити якісний прогноз (прогнозний сценарій) появи основних листогризучих шкідників капусти: совки капустяної (Mamestra brassicacea L.) та білана капустяного (Pieris brassicacea L.) на територіï Полтавської області.

* Науковий керівник-доктор сільськогосподарських наук, професор В. М. Писаренко 


\section{СТОРІНКА МОЛОДОГО ВЧЕНОГО}

Матеріали і методи дослідження. Проводячи ретроспективний аналіз масових розмножень основних листогризучих шкідників капусти: совки капустяної (Mamestra brassicacea L.) та білана капустяного (Pieris brassicacea L.) в Лівобережному Лісостепу України та на території Полтавської області, ми використовували багаторічні дані інституту АПВ ім. М. І. Вавилова. В ході проведених досліджень нами було встановлено наступне.

Совка капустяна (Mamestra brassicacea L.). Уперше масове розмноження цього шкідника згадується в літописі в 1565 році. В Лівобережному Лісостепу України масові розмноження совки капустяної були в 1871, 1878-1879, 1896, 1904-1905, 1908-1909, 1912-1913, 1922-1923, 1928-1929, 1932-1933, 1937-1938, 1956-1957, 1964-1965, 1969-1970, 1975-1976, 1987-1988, 1990-1991, 1995-1996, 1999-2000, 2007 pp. Одночасно масові розмноження совки капустяної відбулися в 1964-1965 pp. - в Україні, Росії, Білорусії, Молдавії, Угорщині, Сербії, Румунії; у 1969 р. - в Україні, Угорщині й Сербії [1, 2].

Білан капустяний (Pieris brassicacea L.). Macoві розмноження цього широко розповсюдженого шкідника капустяних культур Лівобережному Лісостепу України спостерігалися в наступні роки: 1846-1847, 1851-1852, 1854-1855, 1862, $1866,1868,1910,1913,1927,1931-1932,1936-$ 1937, 1947-1948, 1984-1987, 1991-1992, 20012002. Одночасно масові розмноження були в 1927 році - Україна, Німеччина, Білорусія, Грузія, Киргизія, Таджикистан, Росія й Україна в 1986 році. У $1847,1851-1852$ і 1868 році у Прибалтиці спостерігалися цілі хмари метеликів білана капустяного (Pieris brassicacea L.).

$\mathrm{y}$ найбільш поширених комах-шкідників капусти виявлена циклічність у багаторічній повторюваності їх масових розмножень, а саме, цикли 3 періодами 6-7, 9-10 років. Аналогічні часові періоди виявлені дослідниками у повторюваності космічних (сонячна активність), геофізичних і трофічних чинників, що обумовлюють багаторічну динаміку чисельності комах у часі. Крім того, має місце просторова синхронізація масових розмножень совки капустяної, білана капустяного (Pieris brassicacea L.), як одна 3 фундаментальних закономірностей розвитку i функціонування природних систем.

Прогнозування масового розмноження капустяного білана (Pieris brassicacea L.) було започатковано в Україні у 1992 році. Методів прогнозування масового розмноження совки капустяної взагалі не розроблено, але закономірності їх було наведено Л. Я. Сіроус, а також С. В. Довгань [2]. Враховуючи актуальність і практичне значення прогнозування масового розмноження основних шкідників капусти, ми розробили алгоритми прогнозування масового розмноження совки капустяної (Mamestra brassicacea L.) та білана капустяного (Pieris brassicacea L.) на основі теорії циклічності популяцій і міжсистемного методу прогнозування $[1,2,3]$. При цьому використовували хроніки масових розмножень названих шкідників у Лівобережному Лісостепу України, а саме, в Полтавській області. В якості критерію прогнозування використовували роки різких змін сонячної активності (СА), опубліковані в роботі С. М. Білецького [1].

Результати досліджень. Нами розроблено та запропоновано наступні алгоритми прогнозування розмноження шкідників.

Алгоритм прогнозування масового розмноження совки капустяної (Mamestra brassicacea L.)

За 126 років (1871-2007) у названому регіоні було 18 масових розмножень совки капустяної (Mamestra brassicacea L.) у наступні роки: 1871, 1878-1879, 1896, 1904-1905, 1908-1909, 19121913, 1922-1923, 1928-1929, 1932-1933, 19371938, 1956-1957, 1964-1965, 1969-1970. 19751976, 1987-1988, 1990-1991, 1995-1996, 19992000, 2007-2008 [5-9]. Середній період між наступними масовими розмноженнями $(126: 18)=7$ років. У межах циклів сонячної активності розподіл масових розмножень совки капустяної (Mamestra brassicacea L.) був наступним:

\begin{tabular}{|c|c|c|c|}
\hline Роки від сонячних реперів & $\mathbf{- 1}$ & $\mathbf{0}$ & $\mathbf{+ 1}$ \\
\hline $\begin{array}{c}\text { Частота масових } \\
\text { розмножень }\end{array}$ & 0 & 16 & 2 \\
\hline $\begin{array}{c}\text { Імовірність масових } \\
\text { розмножень }\end{array}$ & 0,0 & 88,9 & 11,1 \\
\hline
\end{tabular}

Примітка: 0 - роки сонячних реперів; -1 один рік до реперного року; +1 - через один рік після реперного року.

Із наведеного розподілу масових розмножень у часі випливає, що з імовірністю $88,9 \%$ можна прогнозувати початок наступного масового розмноження совки капустяної (Mamestra brassicacea L.) у Лівобережному Лісостепу України в епоху сонячних реперів і з 100\%-ою через рік після них. Останне масове розмноження цього шкідника було в 2007-2008 pp. із максимумом у 2007 році; до року максимуму додаємо 7 років (середній період між початком масових розмножень) і отже, початок наступного масового розмноження цього шкідника слід очікувати в 2014-2015 роках. 


\section{СТОРІНКА МОЛОДОГО ВЧЕНОГО}

Алгоритм прогнозування масового розмноження білана капустяного (Pieris brassicacea L.)

За останні 155 років було 14 масових розмножень білана капустяного (Pieris brassicacea L.) у Лівобережному Лісостепу України: 1846-1847, 1851-1852, 1854-1855, 1862, 1866, 1868, 1910, 1913, 1927, 1931-1932, 1936-1937, 1947-1948, 1984-1987, 1991-1992, 2001-2002 pp. [5-9]. Середній період між наступними масовими розмноженнями становить 11 років. У межах сонячних циклів розподіл масового розмноження білана капустяного (Pieris brassicacea L.) був наступним:

\begin{tabular}{|c|c|c|c|}
\hline Роки від сонячних реперів & -1 & 0 & +1 \\
\hline $\begin{array}{c}\text { Частота масових } \\
\text { розмножень }\end{array}$ & 1 & 10 & 3 \\
\hline $\begin{array}{c}\text { Імовірність масових } \\
\text { розмножень }\end{array}$ & 7,2 & 71,4 & 21,4 \\
\hline
\end{tabular}

Примітка: 0 - роки сонячних реперів; -1 один рік до реперного року; +1 - через один рік після реперного року.

\section{БІБЛІОГРАФІЯ}

1. Белецкий E. Н. Массовые размножения насекомых. История, теория, прогнозирование. - Х. : Майдан, 2011. - 172 с.

2. Довгаль C. В. Агроекологічні обгрунтування прогнозу розмноження основних шкідливих видів комах в різних грунтово-кліматичних зонах України: Автореферат дис. ... д.с.-г.н. 16.00.10. K., 2010. - 36 c.

3. Сероус Л. Я. Закономерности массовых размножений капустной совки (Mamestra brassicacea L.) в Украине // Вісник ХНАУ, серія «Ентомологія та фітопатологія», 2000. - №3. - С. 174-177.

4. Сборник сельскохозяйственных статей / Библиотека «Хуторянина». - 3-е изд., доп. - Полтава, 1913. - 191 с.
Із розподілу масових розмножень у часі видно, що 3 імовірністю 71,4\% можна очікувати початок наступного масового розмноження білана капустяного (Pieris brassicacea L.) точно в роки сонячних реперів із $92 \%$-ю імовірністю через рік після нього точно в роки сонячних реперів. Останнє масове розмноження цього шкідника було в 2000-2001 роках, із максимумом у 2002 році. До року максимуму додаємо 11 років $\mathrm{i}$ виходить, що наступне масове розмноження цього шкідника з імовірністю 92 \% слід очікувати в 2013 році.

Висновки: 1. Наступне масове розмноження капустяної совки (Mamestra brassicacea L.) на території Лівобережного Лісостепу України та на території Полтавської області слід чекати в 2014-2015 роках.

2. Наступне масове розмноження білана капустяного (Pieris brassicacea L.) на території Лівобережного Лісостепу України та на території Полтавської області слід чекати в 2013 році.

5. Сборник сельскохозяйственных статей / Библиотека «Хуторянина». - 2-е изд., доп. - Полтава, 1917. - 172 с.

6. Сводный зборник по статистическому описанию Полтавской губернии в 1882-1889. - Полтава, 1900. - 279 с.

7. Сводный зборник по статистическому описанию Полтавской губернии в 1893. - Полтава, 1893. -148 c.

8. Обзор развития вредителей сельскохозяйственных культур в 1935-2012 годах в Полтавской области. - Полтава, 2011.

9. Сводъ данных о состоянии сельскаго хозяйства въ Полтавской губернии за 15 лъть (18851900 гг.). - Полтава, 1900. - 297 с. 